\title{
Environmental Impact Assessment of Hydropower Plants in Rwanda: Nyabarongo I Hydropower Plant (NHPP I)
}

\author{
Eustache Hakizimana $^{1, *}$, U. G. Wali ${ }^{2}$, D. Sandoval ${ }^{1}$, KayibandaVenant ${ }^{3}$ \\ ${ }^{1}$ African Center of excellence in Energy for Sustainable Development, University of Rwanda, Rwanda \\ ${ }^{2}$ Department of Civil, Environmental and Geomatics Engineering, University of Rwanda, Rwanda \\ ${ }^{3}$ Department of Mechanical and Energy Engineering, School of Engineering, University of Rwanda, Rwanda
}

Received January 2, 2020; Revised March 31, 2020; Accepted April 19, 2020

Copyright $\bigcirc 2020$ by authors, all rights reserved. Authors agree that this article remains permanently open access under the terms of the Creative Commons Attribution License 4.0 International License

\begin{abstract}
Hydropower is the primary renewable source of energy in Rwanda that harnesses the power of the naturally flowing water streams and its potential is strongly by the hydrological regime. In 2020, overall installed capacity of power was about 224.6 MW. Hydropower makes up approximately $46.8 \%$ of the total installed capacity. $12.8 \%$ is generated from run-of-river Nyabarongo 1 hydropower plant. The aim of this study is to describe the environmental impact assessment of hydropower plants in Rwanda. Nyabarongo I hydropower plant (NHPP I) used a case study and generated and contributed $12.8 \%$ to national installed capacity. A detailed environmental assessment audit approach has been adopted. The outcomes from physical assessment and analysis focus on plant operation and maintenance and end users. The NHPP1 which has a low visible impact, has additionally a minimal effect on the flora and wildlife. GHG emissions of NHPP1 are mainly from production, operation, protection and dismantling. In this physical assessment of NHPP1 the transportation, construction and set up stages have been no longer considered, the NHPP1 is a friendly environment handiest $43 \mathrm{~kg} / \mathrm{MWh}$ is emitted with the aid of a hydro, as a result, the rate of contribution to the reduction of $\mathrm{GHG}$ emissions is very excessive $94 \%$ as compared to the alternative energy in Rwanda.
\end{abstract}

Keywords Hydropower Plant, Environmental Impact Assessment (EIA), Environmental Audit (EA)

\section{Introduction}

Rwanda is located in a tropical, temperate climate due to its high altitude. The average annual temperature ranges between $16^{\circ} \mathrm{C}$ and $20^{\circ} \mathrm{C}$, without significant variations. Rainfall is abundant although it has some irregularities. Winds are generally around $1-3 \mathrm{~m} / \mathrm{s}$. In the higher regions of the Congo-Nile ridge, the average temperature ranges between $15^{\circ} \mathrm{C}$ and $17^{\circ} \mathrm{C}$ and the rainfall is abundant [1] The volcanic region has much lower temperatures that can go below $0^{\circ} \mathrm{C}$ in some places. In areas with intermediary altitude, average temperatures vary between $19^{\circ} \mathrm{C}$ and $21^{\circ} \mathrm{C}$ and the average rainfall is around $1000 \mathrm{~mm} /$ year. Rainfall is less irregular, and sometimes causes periods of drought. In the lowlands (East and Southeast), temperatures are higher and the extreme can go beyond $30^{\circ} \mathrm{C}$ in February and July-August. The absolute temperature of $32.8^{\circ} \mathrm{C}$ was recorded in the southeast by Karama-Plateau station on September, 1980. Thermal constraints are more considerable there than in the remaining part of the Country. Rainfall is also less abundant in that region with around 700-970 $\mathrm{mm} /$ year [2]. Hydropower dominates Rwanda's renewable energy generation. Since 1959, hydropower generation has accounted for more than $47 \%$ of total power generation in Rwanda (Figure. 1), which is much greater than other renewable energy sources such as solar power and thermal power, and is still in steady growth. Compared to other renewable energy sources, hydropower enjoys advantages such as more mature technology, stable operation, and lower operating and maintenance costs.

The electric power supply is significantly inadequate and $47 \%$ of the entire population is gaining access to electricity and Nyabarongo I Hydropower Plant (NHPP1) give $12.8 \%$ to total Rwanda installed capacity. Considering the current shortfall in electricity supply, power generation is set to grow to over $563 \mathrm{MW}$ from its current capacity of 224.6 MW. This research study was specifically based on Nyabarongo I hydropower plant in the southern province of 
Rwanda [3]. The plant is envisaged to utilize the flow of the Nyabarongo River across the loop for the generation of electrical power as a run-of-the-river development. The weather is temperate with two wet seasons (February to April and November to January). Previous studies have not been thoroughly addressed the environmental impact of Hydropower plants from the construction to the use phase. In this paper, we describe the history of hydropower in Rwanda, the current power generation of the country, the contribution made by this renewable energy source and the aim is to describe the life cycle assessment and maximize critical elements of the environmental impacts of NHPP1 in Rwanda. The social impacts of the plant have been assessed but the economic analyses have not considered in this study. The results have been discussed and concluded with the contribution of NHPP1 to the sustainable development of the country.

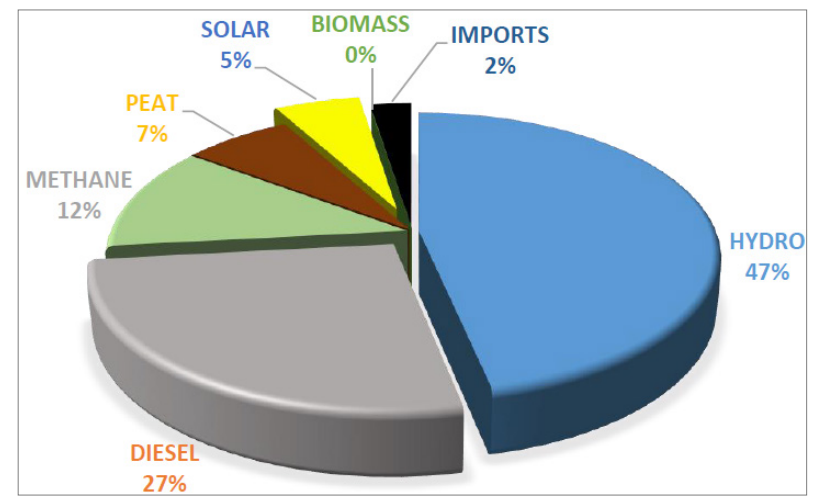

Figure 1. Rwanda's Current Energy Mix [4]

\section{Status of Hydropower Plants in Rwanda}

Rwanda's major Rivers has proven 333 potential sites for Micro-hydropower countrywide. Opportunities exist in Micro and Small Hydropower projects and shared regional hydropower projects in East Africa (EAC) Partners. A couple of micro and mini, small Hydropower Projects are currently under construction. The largest domestic hydropower project is Nyabarongo I, with an installed capacity of $28 \mathrm{MW}$. Table 1 provides a list of the existing hydropower generation plants within Rwanda, as well as their associated characteristics [4]. Figure 2 illustrates the geographical location of hydropower plant in Rwanda.

\subsection{Grid Connected Hydropower Plants}

22 Hydropower plants are grid connected and account to $103 \mathrm{MW}$. They include national and shared regional power plant. Hydropower makes up approx. $46.8 \%$ of the total installed capacity. Hydropower plants are either publicly owned and operated, leased to private companies, or privately owned Independent Power Producers (IPP). The publicly owned power plants are managed by the national utility REG/EUCL. They include larger plants such as Ntaruka, Mukungwa and Nyabarongo I. Independent power producers own and operate 5 plants $(10 \mathrm{MW})$. Other 8 power plants (13 MW) are privately operated through leasing agreements with the Government of Rwanda [3].

\subsection{Off-grid Micro Hydropower Plants/Mini and Small Hydropower}

Currently, 11 micro hydropower plants MW exist in Rwanda as isolating networks. These plants were originally developed by the government of Rwanda and handed over to private sector management to increase the private sector contribution in energy generation. The government of Rwanda has recently leased out these sites to the private investor to better operate, upgrade and connect them to the grid. There is also Pico Hydropower plants in the range of $1-10 \mathrm{~kW}$, which are either publicly owned or operated by the local communities or entirely private. December 2016, 7 privately developed Hydropower plants with a total capacity of $16 \mathrm{MW}$ were under different phases of construction, with commercial operation dates (COD) will plan in 2019. Feasibility studies carried out by the Rwanda Energy Group indicated potential in micro Hydropower generation in over 40 smaller sites [3].

\section{Data Collection}

The research study employs two sources of data, the primary data and secondary source of data. In both parts, the contents include the following methods: Data collection from different sites, the information collected from different journals, textbooks, abstract of inventory report, company manuals and websites. The anaconda/ Jupyter notebooks and QGIS softwares were used for data analysis and visualization. 
Table 1. Existing hydropower generation plants in Rwanda, i.e. ( $\mathrm{COD}=\mathrm{Commercial}$ Operation Date)

\begin{tabular}{|c|c|c|c|c|c|c|c|c|}
\hline No & Plant Name & $\begin{array}{c}\text { Installed } \\
\text { Capacity (MW) }\end{array}$ & $\begin{array}{c}\text { Capacity Factor } \\
(\%)\end{array}$ & $\begin{array}{c}\text { Available Capacity } \\
\text { (MW) }\end{array}$ & Owner & COD & $\begin{array}{c}\text { Type of } \\
\text { Technology }\end{array}$ & $\begin{array}{c}\text { Geographical } \\
\text { Info (Latitude, Longitude) }\end{array}$ \\
\hline 1 & Ntaruka & 11.25 & 23 & 2.5875 & Government of Rwanda & 1959 & Hydro & $-1.477357,29.750290$ \\
\hline 2 & Mukungwa I & 12.00 & 50 & 6 & Government of Rwanda & 1982 & Hydro & $-1.536787,29.683206$ \\
\hline 3 & Nyabarongo I & 28.00 & 48 & 13.44 & Government of Rwanda & 2014 & Hydro & $-1.979420,30.044180$ \\
\hline 4 & Gisenyi & 1.20 & 65 & 0.78 & Prime Energy & 1957 & Hydro & $-1.710112,29.265237$ \\
\hline 5 & Gihira & 1.80 & 70 & 1.26 & RMT & 1984 & Hydro & $-1.766800,30.121900$ \\
\hline 6 & Murunda & 0.1 & 45 & 0.045 & Repro & 2010 & Hydro & $-1.911130,29.372620$ \\
\hline 7 & Rukarara I & 9.5 & 40 & 3.8 & Ngali Energy & 2010 & Hydro & $-2.453851,29.464368$ \\
\hline 8 & Rugezi & 2.6 & 50 & 1.3 & RMT & 2011 & Hydro & -1.507443729 .906345 \\
\hline 9 & Keya & 2.2 & 50 & 1.1 & AdreHydro\&Energicotel & 2011 & Hydro & $-1.704879,29.312893$ \\
\hline 10 & Nyamyotsi I & 0.1 & 60 & 0.06 & AdreHydro\&Energicotel & 2011 & Hydro & $-1.944880,30.062380$ \\
\hline 11 & Nyamyotsi II & 0.1 & 60 & 0.06 & AdreHydro\&Energicotel & 2011 & Hydro & $-1.972970,30.049520$ \\
\hline 12 & Agatobwe & 0.2 & 35 & 0.07 & Carera-Ederer & 2010 & Hydro & $-2.607112,29.745227$ \\
\hline 13 & Mutobo & 0.2 & 45 & 0.09 & Repro & 2009 & Hydro & $-1.508594,29.579923$ \\
\hline 14 & Nkora & 0.68 & 50 & 0.34 & AdreHydro\&Energicotel & 2011 & Hydro & $-1.849609,29.299203$ \\
\hline 15 & Cyimbili & 0.3 & 50 & 0.15 & AdreHydro\&Energicotel & 2011 & Hydro & $-1.822400,29.299900$ \\
\hline 16 & Gaseke & 0.582 & 90 & 0.5238 & Novel Energy & 2017 & Hydro & $-1.768992,30.122833$ \\
\hline 17 & Mazimeru & 0.5 & 49 & 0.245 & Carera-Ederer & 2012 & Hydro & $-1.898150,30.095056$ \\
\hline 18 & Janja & 0.2 & 80 & 0.16 & RGE Energy UK ltd & 2012 & Hydro & $-1.680860,29.681360$ \\
\hline 19 & Gasashi & 0.2 & 40 & 0.08 & Prime Energy & 2013 & Hydro & $-1.806863,29.292631$ \\
\hline 20 & Nyabahanga I & 0.2 & 55 & 0.11 & Government of Rwanda & 2012 & Hydro & $-2.077880,29.416320$ \\
\hline 21 & Nshili I & 0.4 & 60 & 0.24 & Government of Rwanda & 2012 & Hydro & $-2.755641,29.459623$ \\
\hline 22 & RwazaMuko & 2.6 & 60 & 1.56 & RwazaHydroPower Ltd & 2018 & Hydro & $-1.548300,29.629450$ \\
\hline 23 & Musarara & 0.45 & 49 & 0.2205 & Amahoro Energy & 2013 & Hydro & $-2.345900,29.505200$ \\
\hline 24 & Mukungwa II & 2.5 & 73 & 1.825 & Prime Energy & 2013 & Hydro & $-1.581741,29.655042$ \\
\hline 25 & Rukarara II & 2.2 & 52.5 & 1.155 & Prime Energy & 2013 & Hydro & $-2.459405,29.435803$ \\
\hline 26 & Nyirabuhombohombo & 0.5 & 35 & 0.175 & RGE Energy UK ltd & 2013 & Hydro & $-1.944880,30.062380$ \\
\hline 27 & Giciye I & 4 & 40 & 1.6 & RMT & 2013 & Hydro & $-1.695097,29.572642$ \\
\hline 28 & Giciye II & 4 & 40 & 1.6 & RMT & 2016 & Hydro & $-1.972970,30.049520$ \\
\hline \multirow[t]{2}{*}{29} & Ruzizi II & 12.00 & 89 & 10.68 & Government of Rwanda & 1984 & Hydro & $-2.63344,28.90266$ \\
\hline & S-total & 103.16 & & 51.26 & & & & Hydro \\
\hline
\end{tabular}




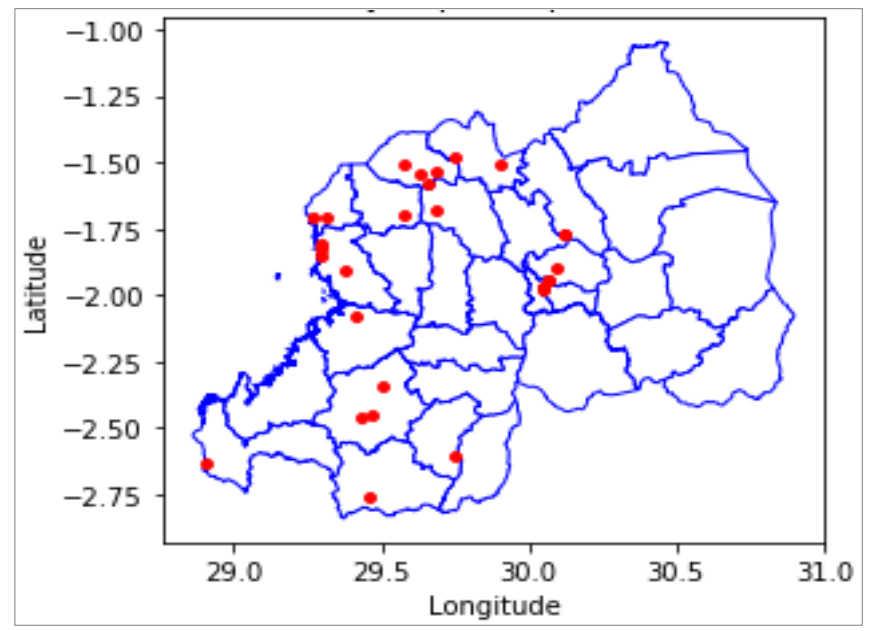

Figure 2. Location of Hydropower plants in Rwanda

Ntaruka and Mukungwa I hydropower plants are in the type of storage power plants which include a dam and a reservoir to impound water, stored and released later when needed. Water stored in reservoirs provides flexibility to generate electricity on demand and reduces dependence on the variability of inflow. Very large reservoirs can store inflow for months or even years, but they are usually designed for seasonal storage, to supply water during dry seasons. As showed in figure 3 there is water reduction during the dry seasons and human protection is needed.

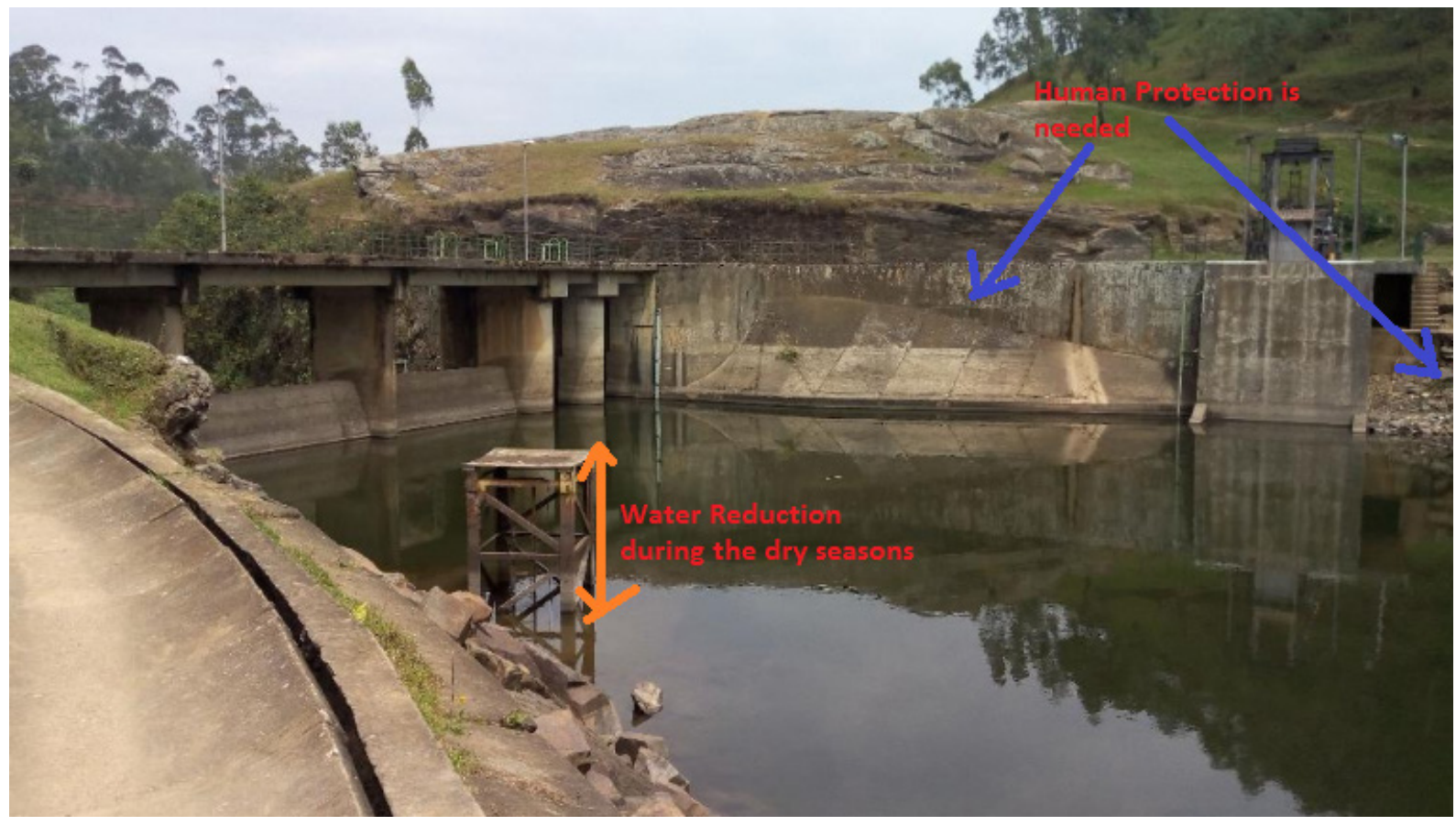

Figure 3. Dam and reservoir of Mukungwa I hydropower plant 


\section{Background of Nyabarongo I Hydropower Plant}

Nyabarongo Power Station is a 28 megawatts (28MW) hydroelectric power station built in Rwanda. The power station is located on the Nyabarongo River, in the Mushishiro sector, Muhanga District, in Southern Province As showed in figure 4. This location lies approximately 75 kilometres, by road, southwest of Kigali, the capital and largest city in Rwanda. Mushishiro lies approximately 35 kilometres, by road, south of the provincial headquarters at Muhanga. The Nyabarongo Power Station is a hydropower plant in Rwanda, completed in October 2014, with a commissioning date in November 2014. At an estimated cost of US\$110 million, the planned capacity installation is $28 \mathrm{MW}[5]$.

The project involves a dam, with run of river design, across the River Mwogo, one of the tributaries of the Nyabarongo River. The project, undertaken by Angelique International Limited \& Bharat Heavy Electricals Limited of India, is the largest hydropower installation in Rwanda, up to date. Naresh Kapoor Sr. General Manager is the Chief Project Officer appointed by Angelique International Limited of India. Part of the engineering work was also subcontracted to the Australian company Snowy Mountains Engineering Corporation (SMEC). Both the units were synchronized to the Rwandan grid on 27 October 2014 and 30 October 2014. The Rwanda government gave the contractor a deadline in October 2014. The power plant is the largest hydropower installation in
Rwanda. It was officially inaugurated by the president of Rwanda on 5 March 2015. They are two generators connected to vertical Francis turbines with an installed capacity of $14 \mathrm{Mw}$, the flow rate of $27.37 \mathrm{~m}^{3} / \mathrm{s}$ and the head of $59.3 \mathrm{~m}$ of each unit [5].

To dates for contributing more than 28MW $(38,000 \mathrm{hp})$ of electricity to the national grid. Power from the Nyabarongo project increases the electrical capacity of Rwandas national grid from $110 \mathrm{MW}$ to $160 \mathrm{MW}$, or about $18 \%$ of the country's energy sector. The power station is located on the Nyabarongo River, in Mushishiro, Muhanga District, in Rwanda's southern Province. This location lies approximately 75 kilometers $(47 \mathrm{mi})$, by road, southwest of Kigali, the capital and largest city in Rwanda. Nyabarongo Main Dam, located on the river in Nyabarongo, is $44.5 \mathrm{~m}$ high above the deep foundation grade and has a length of $242.63 \mathrm{~m}$ at the top. Dam diverts water through the power intake to the head race tunnel leading to a surge shaft and a surface powerhouse. It is intended that a maximum discharge of $54.75 \mathrm{~m}^{3} / \mathrm{s}$ will be diverted for energy generation. The dam would impound approx. $35 \mathrm{MCM}$ (million cubic meters) of water in which approx. 13.37 MCM provides live storage to retain enough water for occasional peaking loads. The reservoir extends up to $22 \mathrm{~km}$ upstream. The dam comprises of total 16 Nos. Overflow (OF) and Non-overflow (NOF) concrete blocks designated in the direction from the left to the right bank as 1 through 16, separated by transverse contraction joints [6]. The qualitative and quantitative data collected from the selected power plant are summarized in the table 2 .

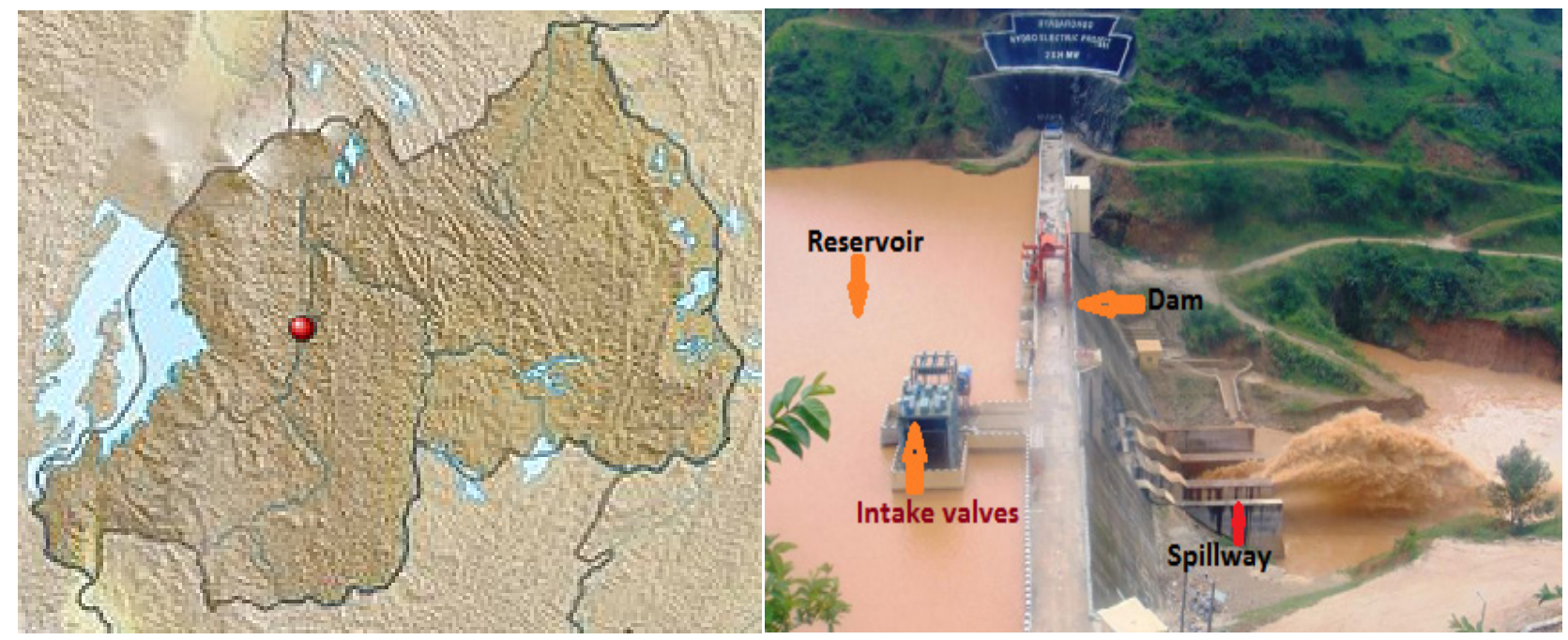

Figure 4. Location of the Nyabarongo I Hydropower plant and Dam [3] 


\section{The Development of Environmental Auditing}

These audits are usually based upon the laws and regulations of the Rwanda Environment Management Authority (REMA). The NHPP1 plant runs 24 hours per day due to the characteristic of a run-of-river system. The power plant uses a vertical Francis turbine (figure 5) in generating the electricity. The Francis turbine is the first hydraulic turbine with radial inflow. Usually, Francis turbines are positioned inside the vertical configuration and suitable for NHPP1. It installs with their axis vertical. Water with a high head (pressure) enters the turbine through the spiral casing surrounding the guide vanes. The water loses a part of its pressure in the volute (spiral casing) to hold its speed. Then the water passes through guide vanes in which it's miles directed to strike the blades on the runner at greater angles. As the water flows through the runner its pressure and angular momentum lessen. This reduction impacts reaction to the runner and power is transferred to the turbine shaft. If the turbine is working at design conditions, the water leaves the runner in an axial direction. Water exits the turbine through the draft tube, which acts as a diffuser and decreases the go out the velocity of the glide to recover most power from the flowing water. For power generation using the Francis turbine is supplied with high pressure water, which enters the turbine with radial inflow and leaves the turbine axially through the draft tube. The energy from water flow is transferred to the shaft of the turbine in the form of torque and rotational. The turbine shaft is coupled to dynamos or alternators for power generation. Quality power generation speed of the turbine should be maintained consistently, in spite of the changing loads. To keep the runner speed constant even in the decreased load condition the water flow rate is reduced through changing the guide vanes the angle.

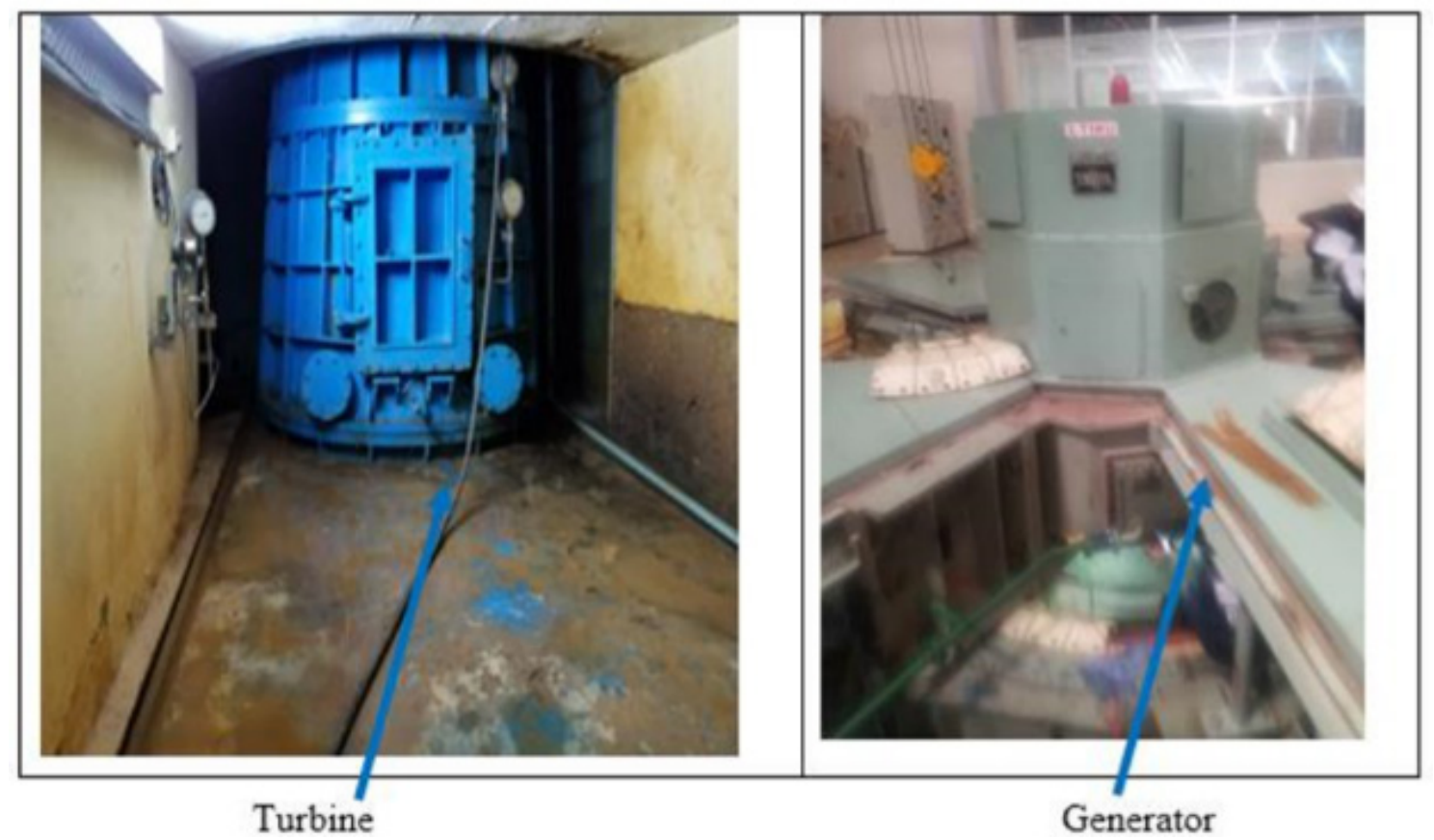

Figure 5. Show a vertical Francis turbine and generator for power production 
NHPP1 is a Run of river type of hydropower plant used the herbal downward flow of rivers and streams for the technology of electricity and the product is directly linked to the national grid. This facility diverts a portion of water flow from the river or stream through a canal or pipe to spin turbines for power generation after which water re-enters the original source. Commonly a small barrage is constructed and if there's a neighborhood head, it's miles exploited. Any dam, if constructed, is for diversion reason simplest; there's no obstruction of water flow. In the case of very low heads, it is convenient to put the plant directly within the river. Francis turbines are radial flow reaction turbines, with fixed runner blades and adjustable guide vanes. The water enters the turbine in a radial direction hanging the blades at a tangent to the drive shaft and exits into the tailrace axially. It commonly uses for medium to high heads. It can be used for head vary among 2.5 meters to 450 meters and can be as large as 800 megawatts.

The plant is designed to provide $150 \mathrm{Gwh}$ per year and assuming that during that time. Simplest two turbines are working. Consequently, the amount of electricity produced in 50 years is approximately $7500 \mathrm{GWh}$. This is derived based on the calculation of electricity produced per hour in 24 hours for 50 years. The reservoir is formed by the construction of a Concrete Gravity dam with spillway crest level at $1476.00 \mathrm{~m}$. The reservoir is operated between full reservoir level (FRL) of $1499.00 \mathrm{~m}$ and Minimum Draw Down Level (MDDL) of $1495 \mathrm{~m}$. This provides live storage of 13.37 MCM between FRL and MDDL. For design flood condition, the reservoir level will rise to the maximum water level of $1499.00 \mathrm{~m}$ with 2 nos. Gates fully open. The reservoir is operated between FRL and MDDL and ensures optimal use of the reservoir for the water supply of turbines to generate power, environmental releases for water requirements downstream. The reservoir shall normally be operated at FRL. Energy/power will be generated depending on the magnitude of the inflow/ turbine discharge. Throughout floods, the surplus water above the turbine discharge will be handled through by using opening the radial gates. Radial gates will be opened (partially or fully) depending on the magnitude of surplus water.
Table 2. The qualitative and quantitative data collected from the plant and REG

\begin{tabular}{|l|l|l|}
\hline S/N & Type of data collected & Quantitative data \\
\hline 1 & Total population (2018) & $12,501,156$ million \\
\hline 2 & Rwanda installed capacity & $218 \mathrm{MW}$ \\
\hline 3 & Households & $46.46 \%(5,808,037$ million $)$ \\
\hline 4 & NHPP1 Installed capacity & $28 \mathrm{MW}$ \\
\hline 5 & NHPP1 Contribute & $12.8 \%$ \\
\hline 6 & $\begin{array}{l}\text { Proximity to population } \\
\text { served }\end{array}$ & 743,428 \\
\hline 7 & Plant load factor & $60.74 \%$ \\
\hline 8 & $\begin{array}{l}\text { Energy generated } \\
\text { kwhe/Year) }\end{array}$ & 122.8 \\
\hline
\end{tabular}

\section{Cumulative Results and Discussion}

Physical assessments and socio-environmental impacts frequently were not taken into consideration within the implementation of energy projects. To assess and evaluate sustainability, numerous distinctive factors want to be taken into consideration. Some of the most important impacts to be taken into consideration include adjustments in the water regime, water quality, changes in biodiversity, population displacement and possible effects of dams on fish migration. The results of the latest review of the literature concluded that as greenhouse gas (GHG) emitters start to be held liable for damages attributable to GHG emissions resulting in weather trade, a high cost for legal responsibility mitigation could offer effective motivations for the deployment of renewable energy technologies. Table 3 shows the yearly generated strength from NHPP1 and at once transmitted to the countrywide grid. The calculated plant load factor is shown in the figure 6 .

Table 3. The annual generated energy for NHPP1

\begin{tabular}{|l|l|l|}
\hline S/N & Year & Total Generation $($ MWh) \\
\hline 1 & $2015-2016$ & 119820 \\
\hline 2 & $2016-2017$ & 108114.2 \\
\hline 3 & $2017-2018$ & 123000 \\
\hline
\end{tabular}




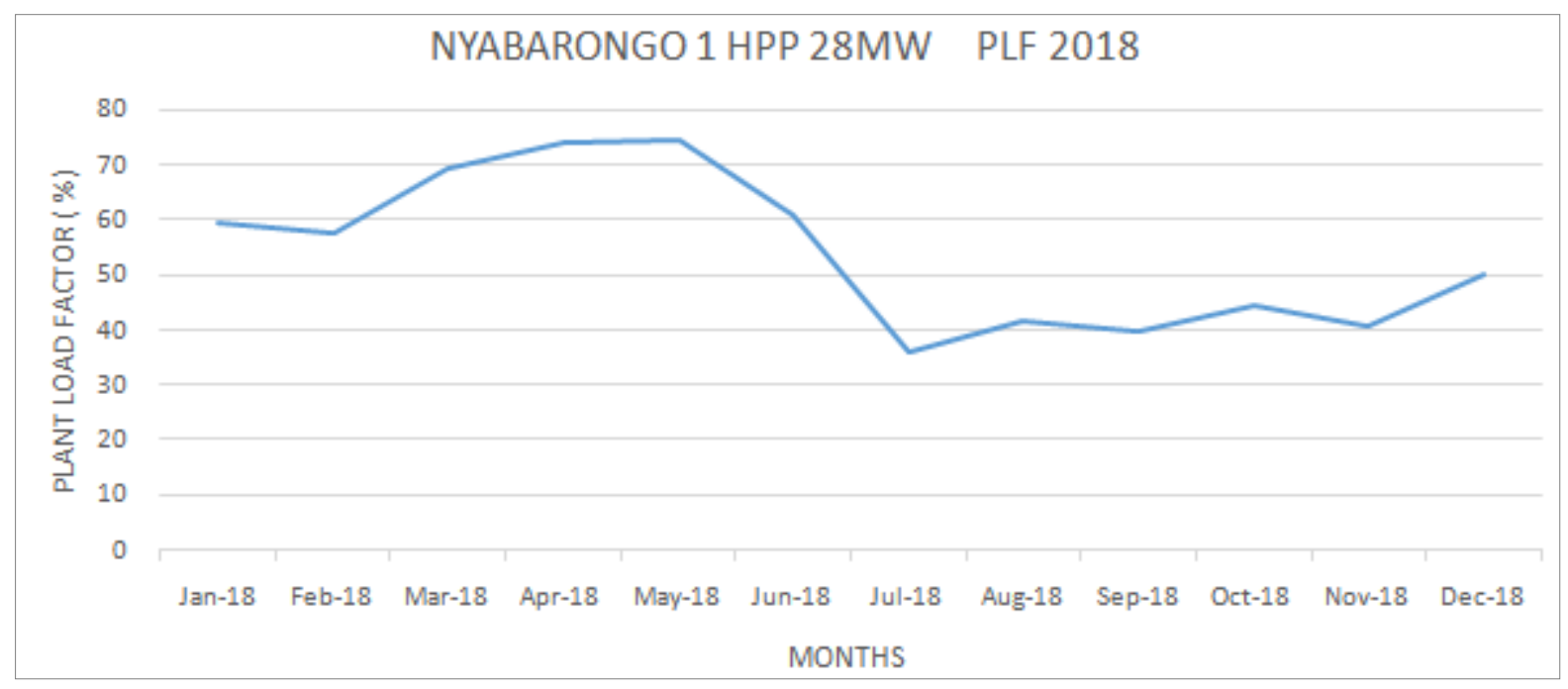

Figure 6. Monthly plant load factor calculated for Hydropower plant

\subsection{Environmental Impact Assessment Results}

The plant is working at complete overall performance as it became designed. Regardless of the unpredictable climate which can also have an effect on the produced power for a positive time in particular inside in the dry season, all different civil, mechanical and electrical infrastructures are completely useful as it became supposed to be. The simplest hazard is excessive sedimentation within the water reservoir resulting from flooding. For the reason that the reservoir is located between mountains, all through heavy rainy seasons, the flood incorporates thousands of tons of soil within the water reservoir. This reduces the usable extent of water and if it maintains it is able to have a major effect on plant production. The effects of the case observe show that the NHPP1 Use the natural waft of a river and diverts a part of the glide, channeling the water to a far-flung powerhouse and eventually returning the diverted float to the river once more. It has also fewer greenhouse gas emissions. Most of those emissions are the results of the construction of the system itself, however, the operation of the plant itself contributes nearly no emissions.

The physical assessment of the plant produced the everlasting noise in the course of hydropower operation because of the turbine, generator and the cooling ventilation is transmitted to the powerhouse structure and may be dangerous to the outside environment. The noise made out of NHPP1 may be minimized via improving the acoustic isolation of the powerhouse and turbine, controlling vibrations of the air flow machine, enhancing the hydrodynamic design of hydraulic systems and by way of using non-reflecting and sound soaking up materials which include fiberglass mat, false ceiling, and heavy mass lure doors. The Environmental impacts of NHPP1 are summarized in table 4. 
Table 4. Summary of environmental impact of the NHPP1

\begin{tabular}{|l|l|l|}
\hline S/N & Parameters & Descriptions \\
\hline 1 & Hydrology & Water quality, sediment concentration \\
\hline 2 & Flood risk & $\begin{array}{l}\text { Is a type of Run-of the river plant, Lowering the flows in a river can alter water temperatures and degrade } \\
\text { habitat for plants and animals }\end{array}$ \\
\hline 3 & Soil & Subsoil (i.e. Acidification) \\
\hline 4 & Air quality & Emissions during construction phase, dust \\
\hline 5 & Noise & Levels in the construction phase and operation \\
\hline 6 & Land use & $\begin{array}{l}\text { Crops around the plant area } \\
\text { Damage to private goods (forestry, agriculture, water supply, ferry traffic) }\end{array}$ \\
\hline 7 & Waste & Waste management during construction phase \\
\hline 8 & Ecology & Impact on ecology during construction and operation \\
\hline 9 & Pollution & No air pollutants, i.e. do not produce toxic byproducts \\
\hline
\end{tabular}

Table 5. Summary of Social impact of the NHPP1

\begin{tabular}{|l|l|l|}
\hline S/N & Parameters & Impacts (Negative/Positive) \\
\hline 1 & Public awareness of the plant & $\begin{array}{l}\text { Impact on local communities. The electricity produced grid is directly connected to the } \\
\text { national grid }\end{array}$ \\
\hline 2 & Health impacts & $\begin{array}{l}\text { Mitigation strategies around health hazards. } \\
\text { Occupational health effects }\end{array}$ \\
\hline 3 & Feeling of local ownership & Involvement of local communities \\
\hline 4 & Willingness to pay & $\begin{array}{l}\text { People living in rural and urban communities paid electricity based on their Ubudehe } \\
\text { categories }\end{array}$ \\
\hline 5 & Community participation & $\begin{array}{l}\text { Local manpower to be hired during construction phase. } \\
\text { Employment benefits and local economic effects }\end{array}$ \\
\hline 6 & Health and safety (workers) & The risk level is very low, safety equipment and workers have the insurance. \\
\hline 7 & Responsibility for service and operation & REG/EUCL \\
\hline 8 & Condition for grid electricity use & $\begin{array}{l}\text { Local electricity and supply electricity for main transmission line. Impacts of } \\
\text { transmission lines on bird populations }\end{array}$ \\
\hline 9 & Type of Hydropower plant & Run-of the river plant (i.e no water storage) \\
\hline 10 & Environmental & Damages to environmental goods and cultural objects \\
\hline
\end{tabular}

\subsection{Social Impacts Assessment Results}

The plant construction forced several human beings to leave the land in alternate for accurate compensation in terms of money. The government constructed a get right of entry to the road to the plant that is used for the area people as nicely to hyperlink with other places. At some stage in construction, neighborhood human beings in each Muhanga and Ngororero district benefited from job opportunities. After the completion of the plant, all houses near the power plant had been given electricity now they've reliable and available electricity. Shop owners, farmer, and different nearby businesses have a growth of their economic system or way to new clients at some stage during and after construction. Displacing and resettling human beings and restoring their livelihoods through the rebuilding or rehabilitation of their communities. The predominant difficulty of the run of the river power plant is to have an effect on human health is the breaching of dams. Properly overall performance in the workplace (station) and make certain that people have coverage/insurance (RSSB, Mutuelle de Sante, and so forth), mobilization and training on the best practices talking to good health and safety in their daily life activities. The social impacts from NHPP1 are summarized in table 5.

\subsection{Operation and Maintenance of the Plant}

The plant is operated with the aid of a team of technicians graduated from neighboring institutions mainly integrated polytechnic regional college (IPRC). The group is made up of electricians and mechanicians. There are two supervisors, one electrical engineer for electricians and a Mechanical Engineer for mechanicians. The supervisor reports to the plant manager. The plant is operated following two parameters: the demand that's determined by means of the National Electricity control Centre (NECC) and the Water stage at the dam which determines the best power that can be delivered. The produced energy is taken to Kilinda substation then to Gikondo substation.

In the rainy seasons, they paintings at complete load whilst within the dry season they function a peaking plant. The preventive maintenance is followed in step with manufacturer requirements that are indicated in equipment manuals. Maintenance Plan is split into every day, weekly, monthly, quarterly and annual maintenance. Periodically 
check and records of equipment overall performance also can be used to decide at the maintenance which can be distinct from the methods given within the guide in phrases of periodicity or activities. In case of a breakdown, they carry out instantaneous reactive maintenance to normalize operations. All maintenance activities are done by way of our group on the plant or sometimes the experienced technical group from the Rwanda Energy Group (REG) can be supported however all are Rwandan and overseas experts aren't wanted. The NHPP1 facilities required minimum maintenance and major components often do not need to replace for decades. Maintenance activities at predetermined time intervals are necessary to ensure the quality and reliable operation of equipment in the service environment through planned, periodic inspection and checking of components and systems, maximum availability of equipment and a minimum of unplanned shutdowns by using planned / periodic shutdowns to inspect all equipment (serviceable and non-serviceable), eradication of operational problems with a timely analysis of the cause of faults / problems and replacement of short term solutions by long lasting and permanent ones.

\section{Conclusions}

The NHPP1 is a fully functional, viable, clean alternative energy source environment-friendly and most important renewable energy source of electricity in Rwanda. Its price-effectiveness, performance, flexible and reliable way to help efficiently sustainable energy guide to the Rwandan communities mainly to complete transformation and enhancement of conservation of the herbal sources which in flip lead to sustainable rural improvement and development of livelihoods. After the location is flooded, the vegetation and soil in those areas decomposes and releases each carbon dioxide and methane. As the plant maintains the environmentally easy and makes a very great contribution to the development of the country. The outcomes from physical assessment and analysis show that the NHPP1 is smooth. It produces only a few greenhouse gases and no different air pollution because it does now not burn any gasoline. It leaves in the back of no waste. Maximum of these emissions is an end result of the construction of the system itself, however the operation of the plant itself contributes almost no emissions. Even as construction and give up of life (decommissioning or demolition) degrees have the finest Acidification ability (AP) and the international Warming ability (GWP) because of the burning diesel gasoline in the constructed system. The environmental concerns from NHPP1 are interference with populations and water float, conflict of land use and other disturbances to the herbal habitat.

In addition, in the running section, the results on the water level can be to expose unpleasant silt margins and to put off water from the watercourses among intakes and power station. The plant is repeatedly plugged as being environmentally pleasant it does no longer want a dam that floods a massive place of land and dramatically remodels the river environment and does no longer emit greenhouse gases. The effect of the plant on land can be great. Creation, get right of entry to the roads and transmission traces motive habit fragmentation, destruction and growth sedimentation inside the Nyabarongo river. A lot of these are a negative effect on the land and river surroundings. Environmental preservation is a key element in developing a Hydropower plant and often dictates many details of construction and operation. It is necessary to investigate, predict and evaluate the potential environmental impact, both during construction and operation and to take sufficient safeguard measure to prevent adverse environmental and social impacts. Potential environmental and social impacts, including sediment transport and erosion, relocation of populations, impact on rare and endangered species, loss of livelihood and passage of migratory fish species in the Hydropower plant.

\section{REFERENCES}

[1] KseniiaMikova, EnockMakupa, John Kayumba. Effect of Climate Change on Crop Production in Rwanda. Earth Sciences. Vol. 4, No. 3, 2015, pp. 20-128. doi: 10.11648/j.earth.20150403.15

[2] Ministry of lands, environment, forestry, water and mines (2006). National adaptation programmes of action to climate change (NAPA). Rwanda. Pp. 85.

[3] https://www.mininfra.gov.rw/index.php?id=79

[4] Rwanda Least Cost Power Development Plan (LCPDP), June, 2019-2050

[5] https://en.wikipedia.org/wiki/Nyabarongo_Power_Station

[6] Peter (22 October 2014). "Nyabarongo To Start Hydro Production In November". Rwanda Energy. Retrieved 24 July 2015

[7] Muyagu, Triphomus (24 March 2014). "Rwanda: Nyabarongo Hydro- Electric Plant to Significantly Boost Energy Supply". New Times (Rwanda) via AllAfrica.com. Kigali. Retrieved 5 March2015.

[8] ISO 14040, "Environmental management Life cycle assessment Principles and framework," the International Standards Organisation (ISO), vol. 3, no. 1, pp. 1-28, 2006.

[9] N.Maximilien, "Design, Costing and Feasibility of Bukaba Micro-Hydropower Plant: a Rwanda Rural Electrification Case Study,” 2013.

[10] BSI, "BSI Standards Publication Environmental management - Life cycle assessment - Requirements and guidelines," Iso 14044:2006, no. May, 2018.

[11] R. Turconi, A. Boldrin, and T. Astrup, "Life cycle assessment (LCA) of electricity generation technologies: Overview, comparability and limitations," Renewable and 
Sustainable Energy Reviews, vol. 28, pp. 555-565, 2013.

[12] J. Hanafi and A. Riman, "Life cycle assessment of a mini Hydropower plant in Indonesia: A case study in Karai River," Procedia CIRP, vol. 29,no. December, pp. 444-449, 2015. [Online]. Available: http://dx.doi.org/10.1016/j.proci r.2015.02.160

[13] V. I. K. Bhat and R. Prakash, "Life Cycle Analysis of Run-of River Small Hydropower Plants in India," The Open Renewable Energy Journal, vol. 1, no. 1, pp. 11-16, 2014.

[14] H. Hondo, "Life cycle GHG emission analysis of power generation systems: Japanese case," Energy, vol. 30, no. 11-12 SPEC. ISS., pp. 2042-2056,2005. 